\title{
Correction to: A Systematic Review of the Evaluation of Interventions to Tackle Children's Food Insecurity
}

\author{
Clare E. Holley ${ }^{1} \cdot$ Carolynne Mason $^{1}$
}

Published online: 4 March 2019

(C) Springer Science+Business Media, LLC, part of Springer Nature 2019

\section{Correction to: Curr Nutr Rep \\ https://doi.org/10.1007/s13668-019-0258-1}

The original version of this article unfortunately contained mistakes in Tables captions. Tables 1 and 2 captions were switched and this should be corrected as follows:

Table 1 Summary of extracted data from papers which evaluate attended interventions which seek to tackle children's food insecurity

Table 2 Summary of extracted data from papers which evaluate subsidy interventions which seek to tackle children's food insecurity

The original article has been corrected.

Publisher's Note Springer Nature remains neutral with regard to jurisdictional claims in published maps and institutional affiliations.

The online version of the original article can be found at https://oi.org/ 10.1007/s13668-019-0258-1

Clare E. Holley

c.holley@lboro.ac.uk

1 School of Sport, Exercise and Health Sciences, Loughborough University, Epinal Way, Loughborough, Leicestershire LE11 3TU, UK 